\title{
Chelating ability of proctolin tetrazole analogue
}

\author{
Elżbieta Łodyga-Chruścińska1 ${ }^{\circledR}$, Daniele Sanna², Giovanni Micera ${ }^{3}$, Longin \\ Chruściński ${ }^{4}$, Jadwiga Olejnik ${ }^{5}$, Ronald J. Nachman ${ }^{6}$ and Janusz Zabrocki ${ }^{5}$ \\ ${ }^{1}$ Institute of General Food Chemistry, Technical University of Łódź, Łódź, Poland; ${ }^{2}$ Istituto C.N.R. Chim. Bio- \\ molecolare, Sassari, Italy; ${ }^{3}$ Department of Chemistry, University of Sassari, Sassari, Italy; ${ }^{4}$ Faculty of Process \\ and Environmental Engineering, ${ }^{5}$ Institute of Organic Chemistry, Technical University of Łódź, Łódź, Poland; \\ ${ }^{6}$ Areawide Pest Management Unit, Southern Plains Agricultural Research Center, U.S. Department of Agricul- \\ ture, College Station, USA; ${ }^{\circledR e-m a i l: ~ e l a l o d y g @ p . l o d z . p l ~}$
}

Received: 06 November, 2005; revised: 25 January, 2006; accepted: 16 February, 2006 available on-line: 23 February, 2006

\begin{abstract}
The aim of the investigation was to establish the chelating ability of a new proctolin analogue of the sequence Arg-Tyr-Leu $\Psi\left[\mathrm{CN}_{4}\right]$ Ala-Thr towards copper(II) ions. The insertion of the tetrazole moiety into the peptide sequence has considerably changed the coordination ability of the ligand. Potentiometric and spectroscopic (UV-Vis, CD, EPR) results indicate that the incorporation of 1,5-disubstituted tetrazole ring favours the formation of a stable complex form of $\mathrm{CuH}_{-1} \mathrm{~L}_{\text {. }}$ This $4 \mathrm{~N}$ coordination type complex is the dominant species in the physiological $\mathrm{pH}$ range. The tetrazole moiety provides one of these nitrogens. The data indicate that $\mathrm{Cu}$ (II) ions are strongly trapped inside the peptide backbone. These findings suggest that $\mathrm{Cu}$ (II) can hold peptide chains in a bent conformation. This bent conformation may be essential for bioactivity of the tetrazole peptides.
\end{abstract}

Keywords: metal complexes, metallopeptides, proctolin, tetrazole peptide analogue

Proctolin (Arg-Tyr-Leu-Pro-Thr) was the first neuropeptide isolated from insects (Brown \& Starratt, 1975). This neuropeptide has been detected in various neuronal cell types of insects (Bishop et al., 1981; O'Shea \& Adams, 1986, Orchard et al., 1989) and identified in neurones with a widespread distribution within the central nervous system of arthropods (Eckert et al., 1981). In order to determine structure-activity relationships for the myotropic activity of proctolin in insects, many modifications of the peptide have been made (Konopińska et al., 1988a; 1988b; Kuczer et al., 1996; Konopińska \& Rosiński, 1999; Woźnica et al., 2004). We have previously described analogues of insect kinins, another class of insect neuropeptides, that retain very significant diuretic activity, modified with a 1,5-disubstituted tetrazole ring $\left(\Psi\left[\mathrm{CN}_{4}\right]\right)$ (Fig. 1), which preferentially forms the type VI $\beta$-turn (Zabrocki et al., 1988; Nachman et al., 2002; 2004). In this study, we have prepared a tetrazole analogue of proctolin. Proctolin was modified at position 3-4 by replacing the Leu-Pro dipeptide unit with the tetrazole dipeptide Leu $\Psi\left[\mathrm{CN}_{4}\right]$ Ala. The interaction of $\mathrm{Cu}(\mathrm{II})$ with proctolin may have physiological relevance because copper content is especially high in synaptosomal fluids which are rich in neuropeptides (Linder \& Goode, 1991). Studies on the $\mathrm{Cu}(\mathrm{II})$-exorphin systems have shown that these exogenous opiate-like peptides are efficient chelating agents (Chruscinska et al., 1997; 1998; Lodyga-Chruscinska et al., 1998; 1999). Moreover, insertion of the tetrazole ring can effectively stabilize the metallopeptide structure (Lodyga-Chruscinska et al., 1999; 2000; 2004; Chruscinska et al., 2001). It has been found that tetrazole ring can be directly involved in the $\mathrm{Cu}$ (II) binding and then very stable complex species with $3 \mathrm{~N}$ or $4 \mathrm{~N}$ co-ordination mode are formed at physiological $\mathrm{pH}$. The complex formation is the result of simultaneous formation of

$\star$ Part of the results were presented at the 18th Polish Peptide Symposium, 4-8 September, 2005, Wrocław, Poland. Abbrevations: CD, circular dichroism; Dab, $\alpha, \gamma$-diaminobutyric acid; EPR, electron paramagnetic resonance; HPLC, high performance liquid chromatography; UV-Vis, electron absorption spectroscopy. 
five-membered chelate rings by consecutive nitrogen donors. The unusual feature found for the $\mathrm{Cu}(\mathrm{II})$ tetrazole enkephalin analogue system has been the cooperative transition from a $2 \mathrm{~N}$ to a $4 \mathrm{~N}$ complex (Lodyga-Chruscinska et al., 1999). The position of the tetrazole ring system in the peptide backbone plays a critical role in the metallopeptide molecule stabilization. The insertion of the tetrazole between amide groups leads to enhanced complex stability and results in a very effective peptide chelating agent. These previous studies led us to investigate copper(II) complexes of proctolin (Scheme 1a) and its tetrazole analogue (Scheme $1 \mathrm{~b}$ ) in order to evaluate the factors governing their chelating ability. The copper(II) coordination to several proctolin analogues modified in the fifth position of the peptide chain have been studied (Kowalik-Jankowska et al., 2005). The presence of a proline residue in the fourth position of the proctolin analogues (RYLPP, RYLPI) led to the existence of the $\mathrm{CuL}$ and $\mathrm{CuH}_{-1} \mathrm{~L}$ complexes with $2 \mathrm{~N}\left\{\mathrm{NH}_{2}, \mathrm{~N}^{-}, \mathrm{CO}\right\}$ and $3 \mathrm{~N}\left\{\mathrm{NH}_{2}\right.$, $\left.2 \mathrm{~N}^{-}, \mathrm{CO}\right\}$ coordination modes, respectively, over a wide $\mathrm{pH}$ range. The amine group of the Dab residue of the RYLP-Dab proctolin analogue was coordinated to copper(II) ions, and a $3 \mathrm{~N}\left\{\mathrm{NH}_{2}, \mathrm{~N}^{-}, \mathrm{CO}\right.$, $\mathrm{NH}_{2} \mathrm{Dab}$ \} complex was found. In this paper, we report the results of combined potentiometric and spectroscopic (UV-Vis, CD and EPR) studies on the copper(II) complexes of proctolin and its tetrazole
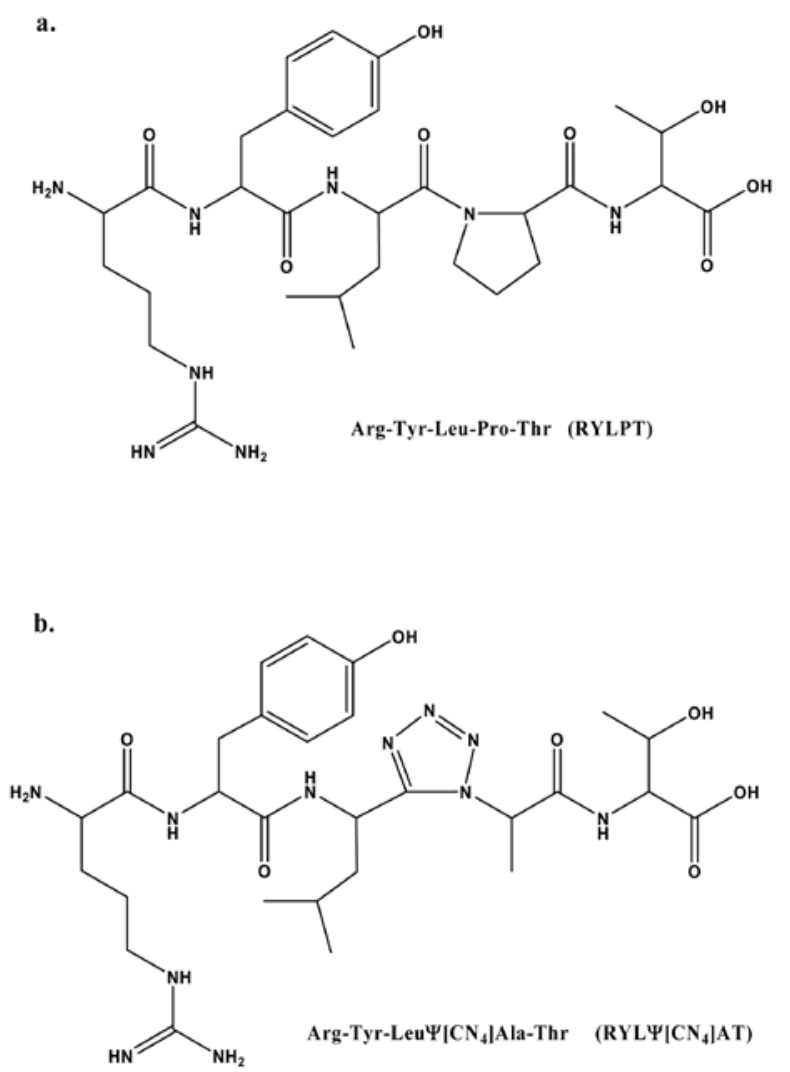

Scheme 1. Proctolin (a) and its tetrazole analogue (b). analogue. The results suggest that the presence of the tetrazole ring enhances the metal binding ability of the peptide.

\section{MATERIALS AND METHODS}

Reagents. The tetrazole proctolin analogue (RYL $\left.\Psi\left[\mathrm{CN}_{4}\right] \mathrm{AT}\right)$ was synthesized according to a previously reported procedure (Zabrocki et al., 1988). Their purity was verified by HPLC, mass spectrometry and potentiometry to be $>99 \%$. Proctolin (RYLPT) was purchased from Bachem and used without purification, $\mathrm{Cu}\left(\mathrm{NO}_{3}\right)_{2}, \mathrm{KNO}_{3}, \mathrm{HNO}_{3}$ and $\mathrm{NaOH}$ were Merck products and were used without further purification.

Potentiometric studies. Protonation and coordination equilibria were investigated by potentiometric titration in aqueous solution, over the $\mathrm{pH}$ 3-11 range, at a constant ionic strength using $0.1 \mathrm{M}$ $\mathrm{KNO}_{3}$ and at constant temperature $(298 \mathrm{~K})$ under argon atmosphere with a total volume of $1.5-2 \mathrm{~cm}^{3}$ of the sample. A $0.05 \mathrm{M}$ solution of $\mathrm{Cu}\left(\mathrm{NO}_{3}\right)_{2}$ was used as the stock for the $\mathrm{Cu}(\mathrm{II})$ ion. An automatic titration set including autoburette meter (Molspin Ltd., Newcastle-upon-Tyne, UK), a semi-microcombined electrode (Russell CMAWL/S7) and an IBM-compatible PC were used to collect data. Alkali, about 0.1 $\mathrm{M} \mathrm{NaOH}$, free of $\mathrm{CO}_{2}$ was added with a $0.250 \mathrm{~cm}^{3}$ micrometer syringe, which was calibrated by both weight titration and titration of standard materials. The electrode was calibrated for hydrogen ion activity. The relationship between activity and concentration was calculated daily by titration with $\mathrm{HNO}_{3}$ (Irving et al., 1967). Calculations were made with the aid of the SUPERQUAD computer program (Gans et al., 1985). This allows the refinement of total ligand concentrations. Therefore we were able to confirm the purity of the peptide, in particular the absence of acetate, a frequent impurity in peptide samples or of other coordinating ions. In all cases triplicate titrations (about 500 experimental points in one set of measurements) were carried out at the $\mathrm{Cu} / \mathrm{L} \mathrm{ra}$ tio of 1:1. The ligand concentration was $1 \times 10^{-3} \mathrm{M}$. As usual, the stabilities of the metal complexes are reported as logarithms of the overall formation constants $\beta_{\mathrm{pqr}}=\left[\mathrm{M}_{\mathrm{p}} \mathrm{H}_{\mathrm{q}} \mathrm{L}_{\mathrm{r}}\right] /[\mathrm{M}]^{\mathrm{p}}[\mathrm{H}]^{\mathrm{q}}[\mathrm{L}]^{\mathrm{r}}$, where $\mathrm{M}$ stands for the metal ion, $\mathrm{H}$ is proton and $\mathrm{L}$ the deprotonated form of the ligand (Table 1). The standard deviations quoted were computed by SUPERQUAD and refer to random errors only. They are, however, a good indication of the importance of a particular species in the equilibrium.

Spectroscopic studies. UV-Vis spectra were recorded with a Perkin-Elmer Lambda 11 spectrophotometer. Circular dichroism spectra were obtained with a Jobin-Yvon CD-6 dichrograph over the 
range 200-750 nm, using 1 and $0.05 \mathrm{~cm}$ cuvettes. The spectra are expressed as $\Delta \varepsilon=\varepsilon_{1}-\varepsilon_{\mathrm{r}^{\prime}}$ where $\varepsilon_{1}$ and $\varepsilon_{\mathrm{r}}$ are the molar absorption coefficients for left and right circularly polarized light, respectively. Electron paramagnetic resonance measurements were carried out with a Varian E-9 instrument at the X-band frequency $(9.1 \mathrm{GHz})$ at $120 \mathrm{~K}$; about $10 \%$ of ethanediol was added to the samples in order to obtain good glasses. Measurements were performed at the maximum concentration of each species found in titrations. The EPR parameters were read from the spectra (estimated uncertainties for $\mathrm{A}$ and $\mathrm{g}$ values are 1 $\times 10^{-4} \mathrm{~cm}^{-1}$ and 0.002 , respectively, in the spectra of a single species).

\section{RESULTS AND DISCUSSION}

\section{Protonation equilibria of free peptides}

The protonation constants of the ligands are included in Table 1 together with some literature data for comparison. Two peptides studied (Scheme 1) contain an arginine at the first position of the peptide backbone. The arginine residue contains a very basic terminal nitrogen atom as a result of resonance stabilization of the protonated guanidine group ( $\log K \approx 12$ ) (Clarke \& Martell, 1970). Under the experimental conditions used, the $\mathrm{pH}$ is $\approx 11$ and, at this value, the degree of deprotonation of the guanidine group is insignificant. Therefore the proton was considered as unionisable under the conditions used and its protonation constant ignored. Both pentapeptides investigated contain three functional groups: the L-tyrosine phenolic, the N-terminal L-arginine $\alpha$-ammonium and the C-terminal threonine carboxyl groups, which deprotonate over the $\mathrm{pH}$ range 3-11. The first protonation constant, $\log \beta_{\mathrm{HL}}=9.76$ or 9.82 for RYLPT and RYL $\left[\mathrm{CN}_{4}\right] \mathrm{AT}$, respectively, refers to the protonation of the tyrosine $\mathrm{OH}$ group. This value is comparable with those of proctolin analogues (Kowalik-Jankowska et al., 2005) and other literature values (Kozłowski et al., 1989; Lodyga-Chruscinska et al., 1999; 2000). The protonation constant of $\mathrm{N}$-terminal L-arginine $\alpha$-ammonium group is similar to that found in RYLPP and RYLPI (Kowalik-Jankowska et al., 2005). For the C-terminal carboxyl group, the acidity decreases in the tetrazole derivative compared to the parent peptide and its analogues. This may be related to the specific conformational changes induced by the tetrazole ring, which makes the deprotonation of C-terminal threonine carboxyl more favorable. The same tendency was also observed in the $\left[\mathrm{Leu}^{5}\right]$ enkephalin tetazole analogue (see Table 1).

\section{Complex formation}

The peptide Arg-Tyr-Leu-Pro-Thr

The stability constants and spectroscopic parameters of the copper(II) complexes of RYLPT and RYL $\Psi\left[\mathrm{CN}_{4}\right]$ AT ligands are collected in Tables 2 and 3.

The best fit for the data obtained from the experimental titration curves for the $\mathrm{Cu}^{2+}-\mathrm{RYLPT}$

Table 1. Stability constants $(\log \beta)$ and calculated protonation constants for RYLPT and RYLYICN $\left.{ }_{4}\right] A T$ and comparable peptides at $298 \mathrm{~K}$ and $\mathrm{I}=0.10 \mathrm{M}\left(\mathrm{KNO}_{3}\right)$

\begin{tabular}{|c|c|c|c|}
\hline Peptide $\log \beta$ & HL & $\mathrm{H}_{2} \mathrm{~L}$ & $\mathrm{H}_{3} \mathrm{~L}$ \\
\hline RYLPT & $9.76 \pm 0.01$ & $16.71 \pm 0.01$ & $20.51 \pm 0.01$ \\
\hline $\mathrm{RYL} \Psi\left[\mathrm{CN}_{4}\right] \mathrm{AT}$ & $9.82 \pm 0.01$ & $16.82 \pm 0.01$ & $19.88 \pm 0.01$ \\
\hline RYLPPa & 9.66 & 16.77 & 20.61 \\
\hline RYLPI ${ }^{\mathrm{a}}$ & 9.54 & 16.73 & 20.69 \\
\hline YGG $\Psi\left[\mathrm{CN}_{4}\right] \mathrm{FL}^{\mathrm{b}}$ & 9.86 & 17.08 & 20.60 \\
\hline AAAAA- $\mathrm{NH}_{2}{ }^{\mathrm{c}}$ & 8.04 & & \\
\hline Stepwise protonation constants (log K values) & $\mathrm{O}^{-}-\mathrm{Tyr}$ & $\mathrm{NH}_{2}$ & $\mathrm{COO}^{-}$ \\
\hline RYLPT & 9.76 & 6.95 & 3.80 \\
\hline $\mathrm{RYL} \Psi\left[\mathrm{CN}_{4}\right] \mathrm{AT}$ & 9.82 & 7.00 & 3.06 \\
\hline RYLPPa & 9.66 & 7.11 & 3.84 \\
\hline RYLPI ${ }^{a}$ & 9.54 & 7.19 & 3.96 \\
\hline YGG $\Psi\left[\mathrm{CN}_{4}\right] \mathrm{FL}^{\mathrm{b}}$ & 9.86 & 7.22 & 3.52 \\
\hline AAAAA- $\mathrm{NH}_{2}{ }^{\mathrm{c}}$ & & 8.04 & \\
\hline
\end{tabular}

${ }^{a}$ Kowalik-Jankowska et al. (2005); 'bodyga-Chruscinska et al. (1999); 'Bal et al. (1993). 
Table 2. Stability constants $(\log \beta)$ of copper(II) complexes with RYLPT and RYLY[CN $\left.{ }_{4}\right] A T$ and comparable peptides at $298 \mathrm{~K}$ and $\mathrm{I}=0.10 \mathrm{M}\left(\mathrm{KNO}_{3}\right)$

\begin{tabular}{|c|c|c|c|c|c|}
\hline Peptide $\log \beta$ & $\mathrm{CuHL}$ & $\mathrm{CuL}$ & $\mathrm{CuH}_{-1} \mathrm{~L}$ & $\mathrm{CuH}_{-2} \mathrm{~L}$ & $\mathrm{CuH}_{-3} \mathrm{~L}$ \\
\hline RYLPT & $13.70 \pm 0.03$ & $8.99 \pm 0.01$ & $1.89 \pm 0.01$ & $-7.81 \pm 0.01$ & $-18.90 \pm 0.01$ \\
\hline RYL $\Psi\left[\mathrm{CN}_{4}\right] \mathrm{AT}$ & $13.60 \pm 0.02$ & $9.35 \pm 0.02$ & $2.66 \pm 0.02$ & $-6.65 \pm 0.02$ & $-17.03 \pm 0.01$ \\
\hline RYLPPa & 13.75 & 8.67 & 1.54 & -7.92 & -18.49 \\
\hline RYLPI ${ }^{a}$ & 13.94 & 8.69 & 1.31 & -8.36 & \\
\hline YGG $\Psi\left[\mathrm{CN}_{4}\right] \mathrm{FL}^{\mathrm{b}}$ & 13.99 & 9.19 & 3.56 & -5.90 & -16.36 \\
\hline AAAAA- $\mathrm{NH}_{2}{ }^{\mathrm{c}}$ & & 4.93 & -0.66 & -8.40 & -16.37 \\
\hline $\begin{array}{l}\log \mathrm{K}^{*} \mathrm{~d} \text { values and deprotonation constants } \\
\text { for amide protons }(\mathrm{pK}) \text { in } \mathrm{Cu}^{2+} \text { complexes }\end{array}$ & $\left\{\mathrm{NH}_{2}, \mathrm{CO}\right\}$ & $\left\{\mathrm{NH}_{2}, \mathrm{~N}^{-}, \mathrm{CO}\right\}$ & $\begin{array}{l}\left\{\mathrm{NH}_{2}, 2 \mathrm{~N}^{-}\right. \\
\left.\mathrm{CO} / \mathrm{N}_{\text {tetr }}\right\}\end{array}$ & $\mathrm{pK}_{1}$ & $\mathrm{pK}_{2}$ \\
\hline RYLPT & -3.01 & -7.72 & -14.82 & 4.71 & 7.10 \\
\hline RYL $\Psi\left[\mathrm{CN}_{4}\right] \mathrm{AT}$ & -3.22 & -7.47 & -14.16 & 4.25 & 6.69 \\
\hline RYLPPa & -3.02 & -8.10 & -15.23 & 5.08 & 7.13 \\
\hline RYLPI $^{a}$ & -2.78 & -8.05 & -15.40 & 5.27 & 7.35 \\
\hline YGG $\Psi\left[\mathrm{CN}_{4}\right] \mathrm{FL}^{\mathrm{b}}$ & -3.09 & -7.89 & -13.52 & 4.80 & 5.63 \\
\hline AAAAA- $\mathrm{NH}_{2}{ }^{\mathrm{c}}$ & -3.11 & -8.70 & -16.44 & 5.59 & 7.74 \\
\hline
\end{tabular}

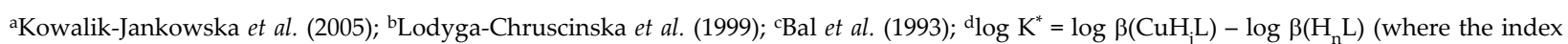
$\mathrm{j}$ corresponds to the number of the protons in the coordinated ligand to metal ion and $\mathrm{n}$ corresponds to the number of protons coordinated to ligand).

system revealed the presence of five metal complex species: $\mathrm{CuHL}, \mathrm{CuL}, \mathrm{CuH}_{-1} \mathrm{~L}, \mathrm{CuH}_{-2} \mathrm{~L}$ and $\mathrm{CuH}_{-3} \mathrm{~L}$ (charges omitted for simplicity, Table 2, Fig. 2).

From the species distribution diagram one can see that the first species is formed above $\mathrm{pH} 5$ (Fig. 2). It is a minor species with metal coordination to the N-terminal amino and nearby carbonyl groups $\left\{\mathrm{NH}_{2}, \mathrm{CO}\right\}$. This species usually shows up in the earlier steps of $\mathrm{Cu}(\mathrm{II})$ complexation by peptides (Sovago, 1990). The CuHL complex cannot be supported by UV-Vis or CD spectroscopy data due to its very low concentration but it was distinguished by a set of EPR parameters: $A_{||}=166 \times 10^{-4} \mathrm{~cm}^{-1}, \mathrm{~g}_{\mid \text {| }}$ $=2.307$ suggesting the $\left\{\mathrm{NH}_{2}, \mathrm{CO}\right\}$ coordination mode (Table 3) (Lodyga-Chruscinska et al., 1999; Pettit et al., 1990). The CuHL species of the peptide with the tyrosyl oxygen protonated corresponds to the $\mathrm{CuL}$ of AAAAA- $\mathrm{NH}_{2}$. The $\log \mathrm{K}^{*}$ values for a $1 \mathrm{~N}\left\{\mathrm{NH}_{2}\right.$, $\mathrm{CO}\}$ complex of proctolin ligand and the complexes<smiles>CCC(C)C(C)n1nnnc1C(C)NI</smiles>

tetrazole

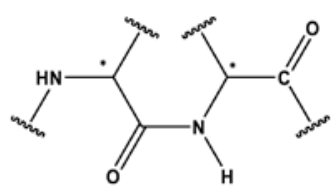

cis-peptide bond
Figure 1. Structure of the tetrazole moiety (left), a mimic of a cis-peptide bond (right).

Asterisks mark chiral centers. of RYLPP, RYLPI and AAAAA- $\mathrm{NH}_{2}$ are comparable to one another supporting the same set of donor atoms involved in copper(II) binding (Table 2). The next complex species with the stoichiometry $\mathrm{CuL}$ is dominant about $\mathrm{pH}$ 6. Its formation is a result of the CuHL deprotonation according to the equilibrium reaction: $\mathrm{CuHL} \leftrightarrows \mathrm{CuL}+\mathrm{H}^{+}$. The deprotonation constant $\mathrm{pK}=4.71$ (Table 2) indicates the deprotonation and coordination of the first amide nitrogen atom to $\mathrm{Cu}(\mathrm{II})$ ion (Lodyga-Chruscinska et al., 1998; Kozlowski et al., 1999).

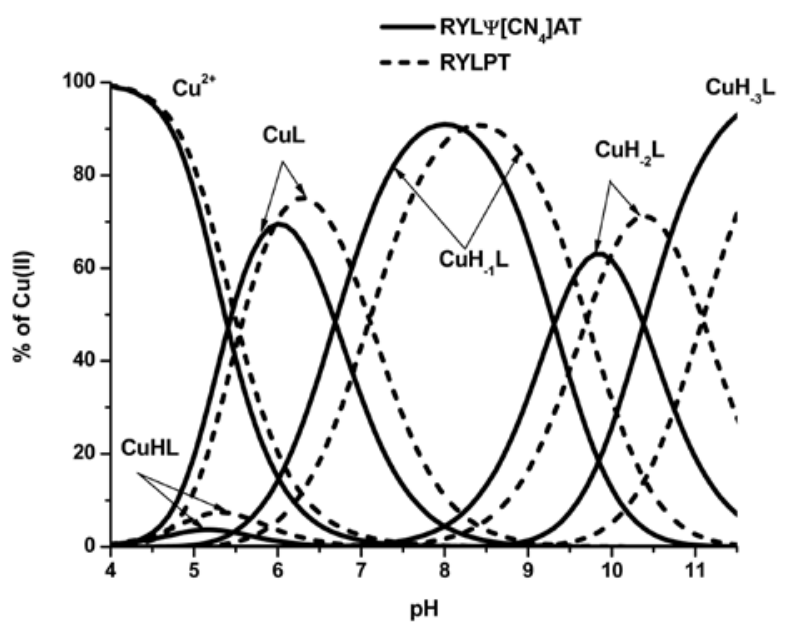

Figure 2. Species distribution of complexes formed in copper(II)-RYLPT (dashed lines) and RYLI $\left[\mathrm{CN}_{4}\right] \mathrm{AT}$ (solid lines) systems.

$\mathrm{Cu}(\mathrm{II})$ to peptide molar ratio $1: 1$, metal concentration 1 $\mathrm{mM}$. 


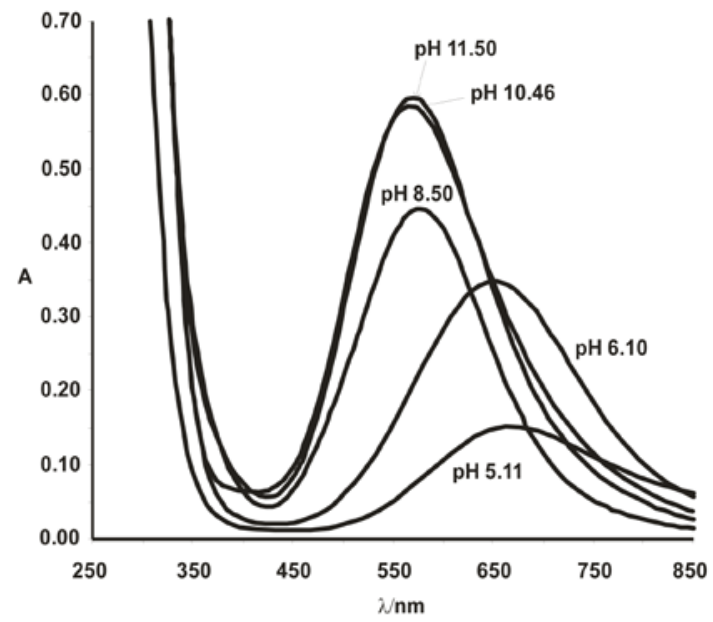

Figure 3. Electronic absorption spectra of Cu(II)-RYLPT system as a function of $\mathrm{pH}$ at $1 \mathrm{mM} \mathrm{Cu}$ (II) concentration and metal to ligand ratio 1:1.

The d-d transition energy at $649 \mathrm{~nm}$ measured from the electronic absorption spectra (Table 3, Fig. $3)$, the presence in $\mathrm{CD}$ spectra of the $\mathrm{N}^{-}{ }_{\mathrm{am}} \rightarrow \mathrm{Cu}^{2+}$ charge transfer transition at $338 \mathrm{~nm}$ (Table 3, Fig. 4) and the EPR parameters: $\mathrm{A}_{||}=175 \times 10^{-4} \mathrm{~cm}^{-1}, \mathrm{~g}_{||}=$ 2.245 support the $\left\{\mathrm{NH}_{2}, \mathrm{~N}^{-}, \mathrm{CO}\right\}$ coordination mode.

The CuL complex loses the next amide proton with increasing $\mathrm{pH}$. The result of this process is the formation of $\mathrm{CuH}_{-1} \mathrm{~L}$ as a major complex species at $\mathrm{pH}$ about 8 (Fig. 2). It has three nitrogen donor atom centers arranged in the equatorial plane of the tetragonal geometry around $\mathrm{Cu}(\mathrm{II})$ ion (Fig. 5a).

The hypsochromic shift of the d-d absorption maximum to $571 \mathrm{~nm}$ in UV-Vis and $580 \mathrm{~nm}$ in CD spectra and the EPR parameters: $A_{\|}=178$ $\times 10^{-4} \mathrm{~cm}^{-1}, \mathrm{~g}_{||}=2.209$ clearly indicate additional amide nitrogen atom binding and the $\left\{\mathrm{NH}_{2}\right.$, $\mathrm{N}^{-}, \mathrm{N}^{-}, \mathrm{CO}$ coordination (Table 3) (Kozlowski \& Micera, 1995). An increase in the $\mathrm{pH}$ above 9 results in the formation of a $\mathrm{CuH}_{-2} \mathrm{~L}$ species (Fig. 2). This complex has a similar binding mode to that of $\mathrm{CuH}_{-1} \mathrm{~L}$ as the $\mathrm{CD}$, absorption and EPR parameters indicate (Table 3, Fig. 4). The protonation constant value of the $\mathrm{CuH}_{-2} \mathrm{~L}$ complex $\left(\log \beta\left(\mathrm{CuH}_{-1} \mathrm{~L}\right)\right.$ $\log \beta\left(\mathrm{CuH}_{-2} \mathrm{~L}\right)=9.70$, see Table 2$)$ is in good agreement with that corresponding to the Tyr side chain in the free ligand $(\mathrm{pK}=9.76)$. This indicates that in $\mathrm{CuH}_{-2} \mathrm{~L}$ the tyrosine $\mathrm{OH}$ group is deprotonated. The phenolic $\mathrm{O}^{-}$of the Tyr residue does not coordinate to the metal ion as was the case in C-terminally modified proctolin analogues (Kowalik-Jankowska et al., 2005). This is supported by the absence of the characteristic charge transfer band at $400 \mathrm{~nm}$ in the UV-Vis or CD spectra (Figs. 3 and 4) (Livera et al., 1988). The next species $\mathrm{CuH}_{-3} \mathrm{~L}$ was detected by potentiometry above $\mathrm{pH} 11$. The spectral parameters estimated at this $\mathrm{pH}$ range indicate that $\mathrm{CuH}_{-3} \mathrm{~L}$ still has the $3 \mathrm{~N}$ coordination with an additional deprot-

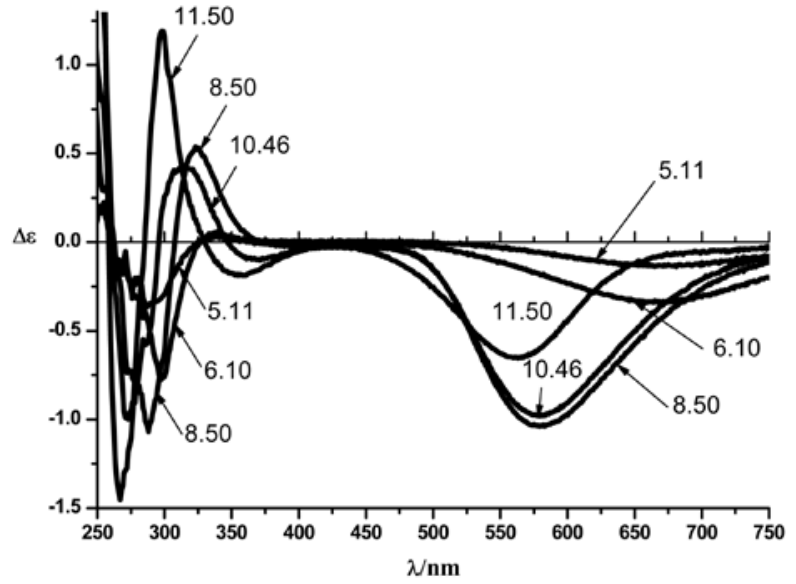

Figure 4. Circular dichroism spectra of Cu(II)-RYLPT system as a function of $\mathrm{pH}$ at $1 \mathrm{mM} \mathrm{Cu}$ (II) concentration and metal to ligand ratio 1:1.

onated water molecule as $\mathrm{OH}^{-}$in the fourth coordination position of the copper(II) ion (Table 3). The protonation constant of this species is 11.09 and corresponds to the deprotonation of the coordinated water molecule (Onindo et al., 1995). The slight splitting observed in the CD spectra (Fig. 4) may reflect some constraints within the peptide backbone due to intraligand interactions following the deprotonation of the water molecule.

The peptide Arg-Tyr-Leu $\Psi\left[\mathrm{CN}_{4}\right]$ Ala-Thr

The stability constants and the species distribution diagram obtained for the tetrazole proctolin analogue is reported in Table 2 and Fig. 2. In the system involving Arg-Tyr-Leu $\Psi\left[\mathrm{CN}_{4}\right]$ Ala-Thr, the fit of the titration curves indicates the same species as were observed for the proctolin: $\mathrm{CuHL}, \mathrm{CuL}, \mathrm{CuH}_{-1} \mathrm{~L}, \mathrm{CuH}_{-}$ ${ }_{2} \mathrm{~L}$ and $\mathrm{CuH}_{-3} \mathrm{~L}$ (Fig. 2). The complex CuHL, with the usual $1 \mathrm{~N}$ coordination mode, exists at a $\mathrm{pH}$ of about 5. It appears only as a minor species and therefore it has been not detected by UV-Vis, CD or EPR spectroscopy. However, with increasing $\mathrm{pH}$, it evolves into the $\mathrm{CuL}$ complex which is the predominant one at a $\mathrm{pH}$ of about 6 . The absorption band of the d-d transition at $685 \mathrm{~nm}$ and the CD parameters (Fig. 6, Table 3) clearly indicate the involvement of $2 \mathrm{~N}$ coordination with the $\left\{\mathrm{NH}_{2}, \mathrm{~N}^{-}, \mathrm{CO}\right\}$ bonding mode (Kozlowski \& Micera, 1995). The EPR parameters show an increase of the hyperfine splitting constant $\left(\mathrm{A}_{1 \mid}\right.$ $\left.=184 \times 10^{-4} \mathrm{~cm}^{-1}\right)$ in comparison to those of RYLPT, RYLPP or RYLPI that may suggest a more stable tetragonal geometry around the copper(II) ion. Some stabilizing effect is also seen in the increase of $\log \mathrm{K}^{*}$ value in comparison to that of proctolin and its analogues (Table 2). At $\mathrm{pH} 8$ the $\mathrm{CuH}_{-1} \mathrm{~L}$ complex was detected. It reveals a species with completely different coordination mode of copper(II) ion than that occurring in the parent peptide or its analogues (Fig. 5b). 
Table 3. Spectroscopic parameters of proctolin and its tetrazole analogue

\begin{tabular}{|c|c|c|c|c|c|c|c|}
\hline \multirow[t]{2}{*}{ Peptide } & \multirow{2}{*}{$\begin{array}{l}\text { Species } \\
\text { Coordination mode }\end{array}$} & \multicolumn{2}{|l|}{$\mathrm{UV}-\mathrm{Vis}$} & \multicolumn{2}{|l|}{$\mathrm{CD}$} & \multicolumn{2}{|l|}{ EPR } \\
\hline & & $\lambda(\mathrm{nm})$ & $\varepsilon\left(\mathrm{M}^{-1} \mathrm{~cm}^{-1}\right)$ & $\lambda(\mathrm{nm})$ & $\Delta \varepsilon\left(\mathrm{M}^{-1} \mathrm{~cm}^{-1}\right)$ & $\mathrm{A}_{\|}\left(10^{-4} \mathrm{~cm}^{-1}\right)$ & $\mathrm{g}_{\|}$ \\
\hline \multirow[t]{27}{*}{ RYLPT } & pH 5.11 & & & $668^{\mathrm{a}}$ & -0.133 & 167 & 2.307 \\
\hline & $\mathrm{CuHL}$ & - & - & $229^{c}$ & +4.398 & & \\
\hline & $\left\{\mathrm{NH}_{2}, \mathrm{CO}\right\}$ & & & $211^{\mathrm{c}}$ & -1.610 & & \\
\hline & $\mathrm{pH} 6.10$ & & & & & & \\
\hline & $\mathrm{CuL}$ & 649 & 87 & $668^{\mathrm{a}}$ & -0.327 & 175 & 2.245 \\
\hline & $\left\{\mathrm{NH}_{2}, \mathrm{~N}^{-}, \mathrm{CO}\right\}$ & & & $338^{\mathrm{b}}$ & +0.071 & & \\
\hline & & & & $291^{d}$ & -0.585 & & \\
\hline & & & & $229^{c}$ & +6.897 & & \\
\hline & & & & $205^{\mathrm{c}}$ & +10.808 & & \\
\hline & pH 8.50 & & & & & & \\
\hline & $\mathrm{CuH}_{-1} \mathrm{~L}$ & 571 & 149 & $580^{\mathrm{a}}$ & -1.011 & 178 & 2.209 \\
\hline & $\left\{\mathrm{NH}_{2}, \mathrm{~N}^{-}, \mathrm{N}^{-}, \mathrm{CO}\right\}$ & & & $324^{\mathrm{b}}$ & +0.555 & & \\
\hline & & & & $291^{\mathrm{d}}$ & -1.072 & & \\
\hline & pH 10.46 & & & & & & \\
\hline & $\mathrm{CuH}_{-2} \mathrm{~L}$ & 571 & 149 & $579^{a}$ & -0.957 & 178 & 2.209 \\
\hline & $\left\{\mathrm{NH}_{2}, \mathrm{~N}^{-}, \mathrm{N}^{-}, \mathrm{CO}\right\}$ & & & $368^{f}$ & -0.072 & & \\
\hline & Tyr-O- ${ }^{-}$deprotonated & & & & & & \\
\hline & & & & $315^{\mathrm{b}}$ & +0.458 & & \\
\hline & & & & $272^{\mathrm{d}}$ & -1.020 & & \\
\hline & & & & $208^{c}$ & +25.654 & & \\
\hline & pH 11.50 & & & & & & \\
\hline & $\mathrm{CuLH}_{-3}$ & 577 & 102 & $562^{\mathrm{a}}$ & -0.628 & 200 & 2.199 \\
\hline & $\left\{\mathrm{NH}_{2}, \mathrm{~N}^{-}, \mathrm{N}^{-}, \mathrm{OH}^{-}\right\}$ & & & $355^{\mathrm{f}}$ & -0.161 & & \\
\hline & & & & $302^{\mathrm{b}}$ & +0.995 & & \\
\hline & & & & $267^{c}$ & -1.453 & & \\
\hline & & & & $241^{\mathrm{d}}$ & +7.692 & & \\
\hline & & & & $210^{\mathrm{c}}$ & +27.766 & & \\
\hline \multirow[t]{28}{*}{ RYL $\Psi\left[\mathrm{CN}_{4}\right] \mathrm{AT}$} & pH 6.19 & & & & & & \\
\hline & $\mathrm{CuL}$ & 685 & 71 & $725^{\mathrm{a}}$ & -0.239 & 184 & 2.225 \\
\hline & $\mathrm{NH}_{2}, \mathrm{~N}^{-}, \mathrm{CO}$ & & & $573 \mathrm{sh}^{\mathrm{a}}$ & -0.153 & & \\
\hline & & & & $330^{\mathrm{b}}$ & +0.154 & & \\
\hline & & & & $293^{d}$ & -0.885 & & \\
\hline & & & & $227^{c}$ & +9.296 & & \\
\hline & & & & $205^{c}$ & +34.520 & & \\
\hline & pH 8.39 & & & & & & \\
\hline & $\mathrm{CuH}_{-1} \mathrm{~L}$ & 547 & 129 & $560^{\mathrm{a}}$ & -0.605 & 201 & 2.204 \\
\hline & $\mathrm{NH}_{2}, \mathrm{~N}^{-}, \mathrm{N}^{-}, \mathrm{N}_{\text {tetr }}$ & & & $332^{\mathrm{b}}$ & +0.281 & & \\
\hline & & & & $291^{\mathrm{d}}$ & -1.894 & & \\
\hline & & & & 227 sh. $^{\mathrm{c}}$ & +18.894 & & \\
\hline & & & & $207^{c}$ & +27.891 & & \\
\hline & pH 10.10 & & & & & & \\
\hline & $\mathrm{CuH}_{-2} \mathrm{~L}$ & 569 & 117 & $605^{\mathrm{a}}$ & -0.430 & 201 & 2.204 \\
\hline & $\begin{array}{l}\mathrm{NH}_{2}, \mathrm{~N}^{-}, \mathrm{N}^{-}, \mathrm{N}_{\text {tetr }} \\
\text { Tyr-O } \\
-\end{array}$ & & & 560 sh. $^{a}$ & -0.350 & & \\
\hline & & & & $323^{b}$ & +0.486 & & \\
\hline & & & & $279^{d}$ & -1.449 & & \\
\hline & & & & $227 \mathrm{sh}^{\mathrm{c}}$ & +10.534 & & \\
\hline & & & & $208^{c}$ & +31.125 & & \\
\hline & pH 11.22 & & & & & & \\
\hline & $\mathrm{CuLH}_{-3}$ & 585 & 110 & $612^{\mathrm{a}}$ & -0.320 & 194 & 2.196 \\
\hline & $\mathrm{NH}_{2}, \mathrm{~N}^{-}, \mathrm{N}^{-}, \mathrm{OH}$ & & & $510^{\mathrm{a}}$ & +0.088 & & \\
\hline & & & & $361^{\mathrm{f}}$ & -0.109 & & \\
\hline & & & & $304^{\mathrm{b}}$ & +1.046 & & \\
\hline & & & & $273^{d}$ & -2.008 & & \\
\hline & & & & $238^{c}$ & +10.580 & & \\
\hline & & & & $210^{c}$ & +34.302 & & \\
\hline
\end{tabular}

${ }^{a} \mathrm{~d}-\mathrm{d}$ transition; ${ }^{\mathrm{b}} \mathrm{N}^{-}{ }_{\text {amide }} \rightarrow \mathrm{Cu}^{2+}$ charge transfer transition; ${ }^{\mathrm{c}}$ intraligand transition; ${ }^{\mathrm{d}} \mathrm{NH}_{2} \rightarrow \mathrm{Cu}^{2+}$ charge transfer transition; ${ }^{\mathrm{f}}$ overlapping $\mathrm{NH}_{2} \rightarrow \mathrm{Cu}^{2+}$ charge transfer transition and intraligand transition. 
a)
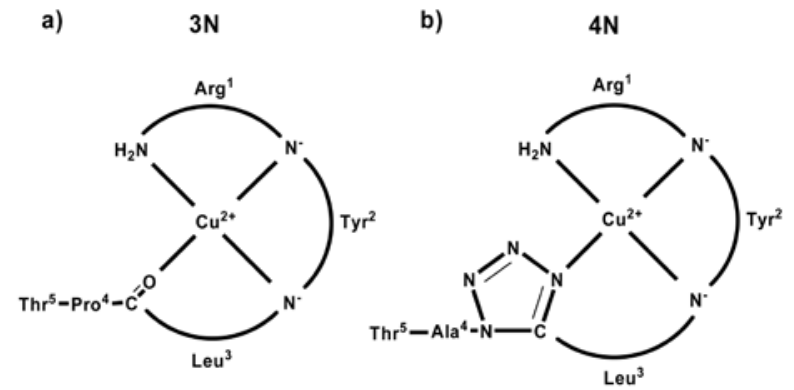

Figure 5. Arrangement of donor atoms identified on the basis of spectroscopic data in the $\mathrm{CuH}_{-1} \mathrm{~L}$ complex of RYLPT (a) and RYLY $\left[\mathrm{CN}_{4}\right] A T$ (b).

The deprotonation constant of the CuL complex (pK value for $\mathrm{CuL} \leftrightarrows \quad \mathrm{CuH}_{-1} \mathrm{~L}+\mathrm{H}^{+}$) equals 6.69 and corresponds very well to the deprotonation and coordination of the third amide nitrogen to copper(II) ion (Kozlowski et al., 1999). The ligand with the phenolate group protonated coordinates the metal via an equatorial donor atom set of the $\left\{\mathrm{NH}_{2}, \mathrm{~N}^{-}, \mathrm{N}^{-}, \mathrm{N}_{\text {tetr }}\right\}$ type. The coordination mode is supported by spectroscopic parameters (Table 3) (Lodyga-Chruscinska et al., 1999). The value of $A_{\|}=200 \times 10^{-4} \mathrm{~cm}^{-1}$ is comparable to that characteristic for the $4 \mathrm{~N}$ species formed in the other oligopeptide-Cu(II) ion systems (Kozlowski \& Micera, 1995). The band of the d-d transition energy seen in UV-Vis or CD spectra of the $\mathrm{CuH}_{-1} \mathrm{~L}$ complex is slightly above that typical of the $4 \mathrm{~N}$ complexes of simple peptides (about $530 \mathrm{~nm}$ ) but this is due to the different nature of the fourth coordinated nitrogen atom, since it is expected that different parameters should be obtained for different nitrogen donor atoms. The $\log \mathrm{K}^{*}$ value for the $\mathrm{CuH}_{-1} \mathrm{~L}$ complex is $0.76,1.07$ and 1.24 orders of magnitude higher in comparison to those of RYLPT, RYLPP and RYLPI, respectively. Some gain in stability can arise from the replacement of the oxygen atom in the copper(II) coordination sphere by the nitrogen atom of tetrazole moiety (see Fig. 5) which exhibits a higher bonding

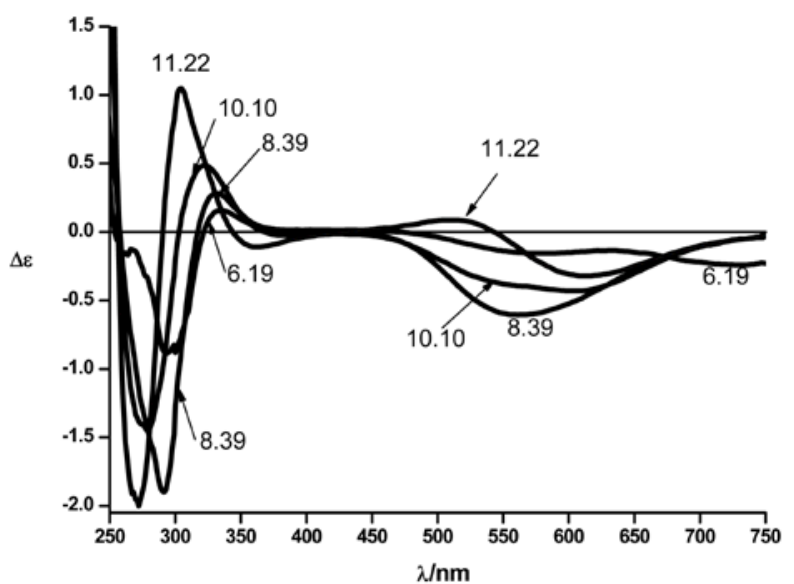

Figure. 6. Circular dichroism spectra of $\mathrm{Cu}(\mathrm{II})-$ RYL $\Psi\left[\mathrm{CN}_{4}\right] \mathrm{AT}$ system as a function of $\mathrm{pH}$ at $1 \mathrm{mM}$ $\mathrm{Cu}$ (II) concentration and metal to ligand ratio 1:1.

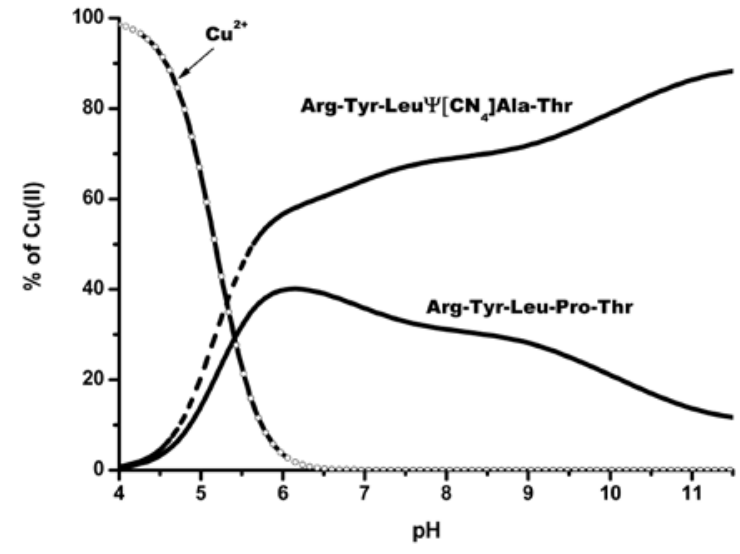

Figure 7. Competition diagram for proctolin (solid line) and its tetrazole analogue (dashed line) in binding of $\mathrm{Cu}$ (II) ions as a function of $\mathrm{pH}$ for 1:1:1 (ligand/metal/ligand) molar ratio and metal concentration $1 \mathrm{mM}$.

affinity for $\mathrm{Cu}$ (II) ion than that of oxygen. This finding could be also attributed to the conformation of the peptide tetrazole analogue that is well suited for metal ion coordination by deprotonated amide nitrogens and the tetrazole nitrogen. The formation of the next complex $\mathrm{CuH}_{-2} \mathrm{~L}$ at a $\mathrm{pH}$ of about 10 is a result of the Tyr side chain deprotonation. The spectroscopic parameters are almost the same as for the $\mathrm{CuH}_{-1} \mathrm{~L}$ species supporting the $\left\{\mathrm{NH}_{2}, \mathrm{~N}^{-}, \mathrm{N}^{-}, \mathrm{N}_{\text {tetr }}\right\}$ coordination mode (Table 3). The last $\mathrm{CuH}_{-3} \mathrm{~L}$ complex species detected by potentiometric titrations is dominant above $\mathrm{pH}$ 11. The presence of the $\mathrm{N}^{-} \rightarrow \mathrm{Cu}$ (II) charge transfer band at $304 \mathrm{~nm}$ in the CD spectrum (Fig. 6, Table 3) supports an involvement of the amide nitrogens in the metal coordination. However, the red shift of the $\mathrm{d}-\mathrm{d}$ transition band and the decrease in the EPR parameters indicate the presence of $\left\{\mathrm{NH}_{2}, \mathrm{~N}^{-}, \mathrm{N}^{-}, \mathrm{OH}^{-}\right\}$ coordination (Table 3). In this complex the weakly basic nitrogen donor atom of the tetrazole moiety is substituted by the $\mathrm{OH}^{-}$group of a deprotonated water molecule $(\mathrm{pK}=10.57)$ (Lodyga-Chruscinska et al., 1999). This coordination mode may lead to a distinct decrease in the geometric symmetry around the metal ion, which results in the splitting of the d-d band observed in the CD spectrum (Fig. 6).

\section{CONCLUSIONS}

The insertion of a tetrazole ring into the peptide sequence changes the coordination towards $\mathrm{Cu}$ (II) ion. Its insertion after the third amino-acid residue leads to the involvement of the tetrazole nitrogen in the metal binding as the fourth donor atom and a gain in the stabilization of the $4 \mathrm{~N}$ complex species. The $\left\{\mathrm{NH}_{2}, \mathrm{~N}^{-}, \mathrm{N}^{-}, \mathrm{N}_{\text {tetr }}\right\}$ coordination mode makes the tetrazole derivative a more effective chelating ligand than proctolin and its C-terminally modified analogues. The enhancement of the bind- 
ing ability is clearly seen in the plot demonstrating the competition between RYLY[CN $\left.\mathrm{CN}_{4}\right] \mathrm{AT}$ and RYLPT ligands towards $\mathrm{Cu}$ (II) ions.

The results indicate that $\mathrm{Cu}$ (II) could hold the peptide chains in a biologically active bent conformation. The extra stability may be attributed to a metal ion-induced conformational organization of the peptide molecule, involving a $\beta$-turn, depending on the nature of the amino-acid residues. This bent conformation achieved may be essential for binding of the tetrazole peptides at the receptor site.

\section{REFERENCES}

Bal W, Kozłowski H, Kupryszewski G, Maćkiewicz Z, Petit LD, Robbins R (1993) Complexes of Cu(II) with Asn-SerPhe-Arg-Tyr- $\mathrm{NH}_{2}$; an example of metal ion-promoted conformational organization which results in exceptionally high complex stability. J Inorg Biochem 52: 79-87.

Bishop CA, O'Shea M, Miller RJ (1981) Neuropeptide proctolin (H-Arg-Tyr-Leu-Pro-Thr-OH): immunological detection and neuronal localization in insect central nervous system. Proc Natl Acad Sci USA 78: 5899-5902.

Brown BE, Starratt AN (1975) Isolation of proctolin, a myotropic peptide, from Periplaneta americana. J Insect Physiol 21: 1879-1881.

Chruscinska E, Dyba M, Micera G, Ambroziak W, Olczak J, Zabrocki J, Kozlowski H (1997) Binding ability of $\mathrm{Cu}^{2+}$ ions by opiate-like fragments of bovine casein. $J$ Inorg Biochem 66: 19-22.

Chruscinska E, Olczak J, Zabrocki J, Dyba M, Micera G, Sanna D, Kozlowski H (1998) Specific interaction of bovine and human beta-casomorphin-7 with $\mathrm{Cu}(\mathrm{II})$ ions. J Inorg Biochem 69: 91-95.

Clarke ER, Martell AE (1970) Metal chelates of arginine and related ligands. J Inorg Nucl Chem 32: 911-926.

Eckert M, Agricola H, Penzlin H (1981) Immunocytochemical identification of proctolin-like immunoreactivity in the terminal ganglion and hindgut of the cockroach Periplaneta americana (L.). Cell Tissue Res 217: 633-645.

Gans P, Sabatini A, Vacca A (1985) SUPERQUAD: An improved general program for computation of formation constants from potentiometric data. J Chem Soc, Dalton Trans 1195-1200.

Irving H, Miles MG, Pettit LD (1967) A study of some problems in determining the stoichiometric proton dissociation constants of complexes by potentiometric titrations using a glass electrode. Anal Chim Acta 38: 475-488.

Konopińska D, Rosiński G, Lesicki A, Sujak P, Sobótka W, Bartosz-Bechowski H (1988a) New N-terminal modified proctolin analogs - synthesis and their cardio-excitatory effect on insects. Int J Pept Protein Res 31: 463.

Konopińska D, Rosiński G, Lesicki A, Sujak P, Sobótka W (1988b) [L-Dopa ${ }^{2}$-Proctolin-synthesis and its high cardioexcitatory properties on cockroach Periplaneta americana. Bull Pol Acad Sci S Chem 36: 17.

Konopińska D, Rosiński G (1999) Proctolin an insect neuropeptide. J Pept Sci 5: 533-546.

Kowalik-Jankowska T, Rajewska A, Szeszel-Fedorowicz W, Konopińska D (2005) Bonding of copper(II) ions by proctolin analogues modified in fifth position of the peptide chain. Polyhedron 24: 443-450.

Kozlowski H, Micera G (1995) Biological fluids in bioinorganic chemistry. In Handbook of Metal-Ligand Interactions
(Berthon G, ed) vol 1, pp 566-582, Marcel Dekker, New York.

Kozłowski H, Radomska B, Kupryszewski G, Lammek B, Livera C, Petit LD, Pyburn S (1989) The unusual co-ordination ability of vasopressin-like peptides; potentiometric and spectroscopic studies of some copper(II) and nickel(II) complexes. J Chem Soc Dalton Trans 173-177.

Kozlowski H, Bal W, Dyba M, Kowalik-Jankowska T (1999) Specific structure-stability relations in metallopeptides. Coord Chem Rev 184: 319-46.

Kuczer M, Rosiński G, Lisowski M, Picur B, Konopińska D (1996) New proctolin analogues modified by D-amino acids in the peptide chain and their high cardioexcitatory effect on tenebrio molitor. Int J Pept Protein Res 48: 289-291.

Linder MC, Goode CA (1991) Biochemistry of Copper. pp 220-231, Plenum Press, New York.

Livera C, Pettit LD, Bataille M, Krembel J, Bal W, Kozlowski H (1988) Copper(II) complexes with some tetrapeptides containing the "break-point" prolyl residue in the third position. J Chem Soc Dalton Trans 1357-1360.

Lodyga-Chruscinska E, Micera G, Szajdzińska-Piętek E, Sanna D (1998) Copper(II) complexes of opiate-like food peptides. J Agric Food Chem 46: 115-118.

Lodyga-Chruscinska E, Micera G, Sanna D, Olczak J, Zabrocki J, Kozlowski H, Chruscinski L (1999) Effect of the tetrazole cis-amide bond surrogate on the complexing ability of some enkephalin analogues toward $\mathrm{Cu}$ (II) ions. J Inorg Biochem 76: 1-11.

Lodyga-Chruscinska E, Brzezinska-Blaszczyk E, Micera G, Sanna D, Kozlowski H, Olczak J, Zabrocki J, Olejnik AK (2000) Can the 1,5-disubstituted tetrazole ring modify the co-ordination ability and biological activity of opiate-like peptides. J Inorg Biochem 78: 283-291.

Łodyga-Chruścińska E, Ołdziej S, Micera G, Sanna D, Chruściński L, Olczak J, Zabrocki J (2004) Impact of 1,5-disubstituted tetrazole ring on chelating ability of $\delta$-selective opioid peptide. J Inorg Biochem 98: 447-458.

Nachman RJ, Zabrocki J, Olczak J, Williams HJ, Moyna G, Ian Scott A, Coast GM (2002) cis-peptide bond mimetic tetrazole analogs of the insect kinins identify the active conformation. Peptides 23: 709-716.

Nachman RJ, Coast GM, Kaczmarek K, Williams HJ, Zabrocki J (2004) Stereochemistry of insect kinin tetrazole analogues and their diuretic activity in crickets. Acta Biochim Polon 51: 121-127.

Onindo CO, Sliva TYu, Kowalik-Jankowska T, Fritsky IO, Buglyo P, Petit LD, Kozłowski H, Kiss T (1995) Copper(II) co-ordination by oxime analogues of amino acids and peptides. J Chem Soc Dalton Trans 3911-3915.

Orchard I, Belanger JH, Lange AB (1989) Proctolin: a review with emphasis on insects. J Neurobiol 20: 470-496.

O'Shea M, Adams M (1986) Proctolin: from 'gut factor' to model neuropeptide. Adv Insect Physiol 19: 1-28.

Pettit LD, Gregor JG, Kozlowski H (1990) In Perspectives on Bioinorganic Chemistry (Hay RW, Dilworth JR, Nolan KB, eds) vol 1, pp 16-27, JAI Press, London.

Sovago I (1990) Metal complexes of peptides and their derivatives. In Biocoordination Chemistry: Coordination Equilibria in Biologically Active Systems (Burger K, ed) pp 135-184, Ellis Horwood.

Woźnica I, Szeszel-Fedorowicz W, Rosiński G, Konopińska D (2004) Biological evaluation of analogues of an insect neuropeptide proctolin. Acta Biochim Polon 51: 115-119.

Zabrocki J, Smith GD, Dunbar JB, Iijima H, Marshall GR (1988) Conformational mimicry. 1 1,5-Disubstituted tetrazole ring as a surrogate for the cis amide bond. $J$ Am Chem Soc 110: 5875-5880. 